\title{
Environmental performance of a petrochemical company after ISO 14001 certification
}

\author{
L. L. Brandli, D. Martinkoski, C. I. Goellner, M. A. L. Frandoloso \\ \& A. G. de Abreu \\ Faculdade de Engenharia e Arquitetura, \\ Universidade de Passo Fundo, Brazil
}

\begin{abstract}
The object of this article is to analyze the environmental indicators for a petrochemical organization that has EMS certification from the NBR ISO 14001.

Research methodology was adapted from the case study carried out in Compania Petroquímica do Sul (South Petrochemical Company) - COPESUL, located in the South petrochemical complex in Triunfo, Rio Grande do Sul, Brazil and is therefore included in this research for the Brazilian Petrochemical sector, the company of this study, within the petrochemical context. Results include evidence of: analysis of generated residues from production, environmental monitoring and energy and water consumption. Based on the data presented by the company it was possible to provide an analysis of their environmental performance which was conclusively considered positive.

Keywords: environmental management, environmental performance, cost/benefit analyses, ISO 14001.
\end{abstract}

\section{Introduction}

Environmental questions have become an obligatory part of the organizations executive agenda [1], in order to adhere to current market requirements and to follow current trends of sustainability, companies have been opting for environmental seals and certification. Nevertheless, the realization of maximizing environmental preservation requires great investments from organizations which, in the short term do not usually present apparent profits. However, there are many benefits following EMS certification which include: 
image improvement, increased eco-efficiency leading to an increase in the production processes and decrease of environmental costs.

From this it can be been that the costs/benefits are fundamental with regards to the financial returns following environmental procedures. To facilitate the position accomplished of effective cost/benefit output, it is necessary to control information, closely monitor all environmental considerations, control all performance indicators and maintain a rigorous control over all environmental costs.

Knowledge of the relationship between costs and investments associated with economies and benefits can affect decisions concerning the implantation of environmental management systems.

The objective of this study therefore is to analyze an organization's environmental performance indicators, following EMS certification by the NBR ISO 4001, and establish the relationship between cost/benefit with the investment and financial return achieved by the company.

The research was carried out by COPESUL, with its EMS certified by NBR ISO 14001, emphasizing the resulting environmental indicators with regard to the fixed costs and investments forecast for EMS maintenance and the benefits obtained from these actions.

According to Souza [2] in the decade of the 90s, many organizations began to integrate environmental and business tactics, following the arrival of a new and strategic environmental paradigm, which Varadarajan [3] called "enviropreneurial marketing". This can be defined as the beneficial marketing activities of companies with an environmental business aspect, with the company economy being the main objective of social and environmental performance.

In such cases, the companies' actions become pro-active, acting on prevention instead of recovery, and come to be utilized as a competitive strategy, associated with the improvement of the company image.

The sharing of positive experiences achieved by the companies produces environmental benchmarking, which is practiced as a learning tool by means of competitive comparisons, with emphasis on the processes and results of the companies that are recognized as representatives of the best environmental practices.

A good example of environmental benchmarking is the Environmental Management Systems implantation and its adhesion to the Norm ISO 14001.

To obtain benefits through this system, the organizations need a structure and a culture free from barriers, so as to be able to organize a sustainable society. This objective can be achieved with the aid of several elements, such as tools, structures, principles and norms, including the ISO 14001 and through these elements obtain from the environmental management a strategy for sustainability [4].

To instigate and implement the process of an EMS and the certification process ISO 14001, companies require two phases, with an initial and obligatory strategic costs management program being initiated.

According to the authors Shank and Govindarajan [5], Hansen and Mowen [6] and Libera [7], the traditional vision of costs has always been utilized 
through the valuation of the financial results from the high management decisions of the company. Immediately, the strategic management of costs can be understood in a different way because cost analysis can be treated, or cited, under a broader context, where the strategic elements become more obvious, explicit and formalized; and an integral comprehension of the costs can create a competitive advantage for the company.

From this it can be seen that it is indispensable to manage costs in a strategic manner and to direct the organizational structure towards an environmental perspective.

It rapidly becomes apparent that an internal evaluation of the costs is necessary, which according to Jasch [8] necessitates understanding of the relationship between internal and external costs and to relate all such costs to the safeguarding (protection, prevention and damage reparation) of the environment against degradation.

The company goals can be accompanied through the Environmental Performance Indicator - EPI that, according to Lavorato [9], is understood as "quantitative or qualitative expressions that supply information about determined variables and their inter-relations. This means having at $=$ and indispensable information for continuous improvement processes for the companies".

According to Gheno [11] the indicators selected, expressed in relative values, should be interpreted and evaluated in the sense of identifying the critical environmental aspects, accomplishments and deficiencies of the companies' environmental performances, which can take as their case the NBR ISO 14031 [10] which, according to ABNT, treats specifically the directives for the Environmental Performance Evaluation - EPV, and the adoption of the environmental Performance Indicator - EPI.

According to Reis [12], and Tibor and Feldman [13], environmental performance is the training period undertaken by an organization in the treatment of the relations among all the aspects of its activities and its risks and significant environmental effects, and consists of obtaining measurable results from the managerial environmental aspects of the activities, products and services of an organization.

Based on the conceptualization of the authors cited previously, and starting with the presumption that what was measured can be evaluated, this same measure allows the organization to understand and quantify the indicator, enabling a clearer vision of where the problems are and how to achieve the objectives.

\section{Research method}

This work uses the technique of exploratory and descriptive research, using the case study method and having considered the company performance in the petrochemical branch: COPESUL. The research describes and evaluates the environmental performance of the organization between 1996 and 2005. The analyzed indicators were: atmospheric emissions, liquid effluents, solid residues and water and energy consumption. 
The sources of evidence used to conduct this research were:

I. Annual Performance Reports, which are disclosed by the company in printed form, as well as in digital format. The document production is accomplished by the People Management Office Sector and the Organization for Safety and Environment, which make use of obtained information through external and internal audits conducted by the Certifying Body;

II. Information obtained through electronic and telephonic communication with the Management people, Safety and Environment;

III. Researchers' visits to the company for viewing of the production process.

\section{Environmental management in COPESUL}

The Brazilian petrochemical complexes are installed in São Paulo (SP), Camaçari (BA) and Triunfo (RS). Maranhão [14] defines the petrochemical industry as the chemical industry that utilizes oil as the raw material including products derived from natural gas.

COPESUL, located in Triunfo, possesses programmes of environmental management focused on the prevention of environmental impacts and have as their goal eco-efficiency. These environmental programmes are realized in the company using the following principles: atmospheric emissions minimization; effluence generation minimization; minimization of residues generated at origin; recycling; re-use and/or recuperation of water and energy; rational use of natural resources and eco-efficiency.

The sources of atmospheric emissions of the company are divided into two main groups, one located in the petrochemical processing units and the other in the Central Utilities operation.

Among these technologies of output and environmental protection adopted by the company is the inclusion of natural gas in the energy matrix, the substitution of the existing coal by a type with greater heat power and smaller ash and sulphur content; and the adoption of new technologies of environmental protection in the loading road and bottom loading operations.

With regard to the atmospheric emissions control, the following are included:

- Tanks and spheres - the majority of the product tanks receive nitrogen injection for "inertisation" aiming to avoid loss of hydrocarbon in the case of leakage. Benzene and MTBE are equipped with floating roves which reduce the products volatility and their emissions into the atmosphere.

- $\quad$ Flares - the flares receive and carry out controlled burning of gases currently diverted from the process by security or control measures. The burning system is supplied with low pressure steam which operates the process at low temperatures and produces flares without smoke.

- Boilers - the cold boilers are equipped with electrostatic precipitators which abate $99 \%$ of particulate material present in the combustion gases. Smoke stacks of $120 \mathrm{~m}$ height guarantee the dispersion in optimum conditions. 
In relation to the COPESUL [15] report, the effluents are classified in the company as Organic and Inorganic and Pluvial non-contaminating. The effluents receive pre-treatment and are then sent to SITEL (Integrated System of Liquid Effluent Treatment) as two types: organic and inorganic.

The solid wastes generated in the company are separated and classified in relation to the kind and level of danger they present. In the management of solid waste the company focuses its efforts at the source of generation control in the reuse and recycling. If these alternatives are not viable the residues are conducted for treatment or final disposal according to the best available technology [15].

This reduction in the generation of solid waste of the material with recycling potential besides promoting environmental gains, reduces potential impacts of the final disposition and also results in economic gains, because these wastes are recovered and/or reused within the company.

The SICECORS - Sistema Centralizado de Controle de Resíduos Sólidos (Centralised Control System of Solid Waste), was improved by the company in 1983 and currently operated by CORSAN - Companhia Rio Grandense de Saneamento (Sanitation Company of Rio Grande do Sul), it centralizes the collection, treatment and solid waste disposal generated in the South petrochemical Complex. The central collection disposes waste to sanitary landfill sites, TDD (Treatment and Disposal Ditch) and stockyards of barrels containing waste destined for the Landfarming and Landspreading systems.

As the centre for the raw material of the Complex Utilities, COPESUL is responsible for water capture and its treatment for the generation of many grades of water necessary for industrial processes. These range from clarified water to water of high purity as well as potable water and water for fire fighting.

As part of the energy matrix, the company creates from its installation electrical energy for usage and currently operates with natural gas, coal and fuel oil [15].

\section{The environmental performance analysis of COPESUL}

The environmental performance data is presented using three analytic methods. The first is through the presentation of water and energy consumption, emissions, effluence and solid wastes produced and their variations during the 1996-2005 period. The second analysis is accomplished by the interpretation of the charts produced and the information contained within them. The third analysis is conducted through studying elements of the company's environmental performance. This analysis first shows a correction in 1996 of more than 39.6\% due to the enlargement of the company's production capacity, which also occurred between 1997 and 1999. A comparison is then made of the year anteceding EMS certification against the average of the subsequent years following environmental management. It is then possible to observe the volume variation in the percentage of each of the elements. 


\subsection{Emissions}

The substances released as atmospheric emissions are: particulate material, sulphur dioxide, nitrogen dioxide, carbon monoxide and volatile organic compounds.

With regard to the particulate material and nitrogen dioxide, it is observed that after the environmental certification, the years with the highest numbers of these components coincided with the years of maintenance shutdown of the company. Considering that maintenance activity has as its principal objective the cleansing of production elements, this implies that the increase is not attributable to the fault of control and monitoring processes but to the need for continuing improvement.

Analyzing the emission of sulphur dioxide and volatile organic compounds (VOCs), the data in Table 1 shows little variation in these components which can be neither interpreted as progress nor failure after obtaining environmental certification.

Carbon monoxide emissions show a gradual increase since 1996. However, the rates still comply with the legal standard for air emissions and are therefore acceptable.

Taking this analysis further, if the company continued increasing the pollution load of its atmospheric emissions, it may exceed the acceptance levels, and would be liable to fines and penalties. Therefore the reduction of air pollutants becomes of economic benefit, although this cannot currently be quantified.

Table 1: Variation rates (\%) of atmospheric emissions after SEM implantation.

\begin{tabular}{|c|c|c|c|c|}
\hline Years & $\begin{array}{c}1996 \\
(+39.6 \% \\
\text { amplification })\end{array}$ & $\begin{array}{c}\text { Average of } \\
\text { Period of } \\
1997- \\
2005 \\
\end{array}$ & $\begin{array}{c}\text { Reduction } \mathbf{f} \\
\text { generated } \\
\text { value in the } \\
\text { period (t/ano) }\end{array}$ & $\begin{array}{c}\% \\
\text { Variation }\end{array}$ \\
\hline $\begin{array}{l}\text { Particulate } \\
\text { Material }\end{array}$ & 3979.2 & 292.6 & 3686.6 & -92.6 \\
\hline $\begin{array}{l}\text { Sulphur } \\
\text { Dioxide }\end{array}$ & 14459.4 & 4318.2 & 10141.2 & -70.1 \\
\hline $\begin{array}{l}\text { Nitrogen } \\
\text { Dioxide } \\
\end{array}$ & 9128.8 & 3271.6 & 5857.2 & -64.1 \\
\hline $\begin{array}{l}\text { Carbon } \\
\text { Monoxide } \\
\end{array}$ & 913.4 & 780.6 & 132.8 & -14.5 \\
\hline VOCS & 3381.2 & 2475.1 & 906.1 & -26.7 \\
\hline
\end{tabular}

When comparing the averages between 1997 and 2005 of all substances with the volumes generated in 1996 (adjusted for more than $39.6 \%$ of production expansion) it is clear that there were improvements in the emission quantities of all components, with reductions ranging between $14.5 \%$ and $92.6 \%$, represented 
by more than 132000 tons of carbon monoxide and by more than 3 million tons of particulate material. With this, it can be concluded that the EMS certified by NBR ISO 14001 [15] was fundamental in achieving this reduction.

\subsection{Effluents}

The research shows the volume of liquid effluent, both organic and inorganic, in $\mathrm{m}^{3}$ per year during the period examined as the total generated annually. From this data, the total values produced have been calculated as the average generated in the analyzed period which represents the parameters for analysis of environmental performance.

After the expansion of installed capacity in 1998, the volume of organic effluent continued to increase until 2002 after which, due to the investments made with a focus on reducing the generation of organic effluents showed a decrease in the annual volume generated. The inorganic effluent showed a variation year by year presenting a unique differentiation in 2005 when there was an increase above the average. The cessation of equipment maintenance instigated by the company in 1996, 2001 and 2005 had a direct influence on the volume of effluent generated both for organic and inorganic waste, verified by the data of 2005 which clearly shows an increase on the generation of inorganic effluents and a decrease in the generated volume of organic effluents.

Table 2 shows the generated volume of organic effluents in 1996 (values corrected according to the percentages of company expansion) compared to the average in the period from 1997-2005 presenting a reduction of over $12 \%$ in generated volume $\left(\mathrm{m}^{3}\right)$, information which represents improvement both from the environmental and financial points of view, confirming the monetary value of reducing the generation of these organic effluents.

Table 2: $\quad$ Variation index (\%) in the liquid effluents generation.

\begin{tabular}{|l|c|c|c|c|}
\hline Years & $\begin{array}{c}\mathbf{1 9 9 6} \\
\mathbf{( + 3 9 . 6 \%} \\
\text { expansion) }\end{array}$ & $\begin{array}{c}\text { Period } \\
\text { Average } \\
\mathbf{1 9 9 7 -} \\
\mathbf{2 0 0 5}\end{array}$ & $\begin{array}{c}\text { Reduction of } \\
\text { generated } \\
\text { volume in the } \\
\left.\text { period } \mathbf{( m}^{\mathbf{3}}\right)\end{array}$ & \% Variation \\
\hline Organic & 1936.748 & 1698.701 & 238.047 & -12.2 \\
\hline Inorganic & 1414.187 & 1090.168 & 324.019 & -22.9 \\
\hline TOTAL & 3350.935 & 2788.869 & 562.066 & -16.7 \\
\hline
\end{tabular}

As regards the inorganic effluent; comparing the period under study (19972005) with 1996, the information showed a reduction in the generated volume even greater than the organic effluent, with a reduction of $22.9 \%$. Considering the indicators pointed out, as well as the volume reduction of generated liquid effluent, it is clear that the EMS is being implemented with efficiency and the quest for continuous improvement is intrinsic in the policy of the company under study. With the indicators of environmental performance, it is possible to observe the changing of the pollution load of liquid effluents (where there is 
evidence that all parameters were reduced) if compared to 1996 with the average in the period. Table 3 shows a reduction higher than $40 \%$ for all parameters of the pollution load of liquid effluents. This indictor of environmental performance shows the efficiency with which EMS operates which is reflected directly in the positive results achieved.

Table 3: $\quad$ Index of discounting (\%) of pollution load in liquid effluents.

\begin{tabular}{|l|c|c|c|c|}
\hline Years & $\begin{array}{c}\mathbf{1 9 9 6} \\
\mathbf{( + 3 9 . 6 \%} \\
\text { expansion) }\end{array}$ & $\begin{array}{c}\text { Period } \\
\text { Average } \\
\mathbf{1 9 9 7 -} \\
\mathbf{2 0 0 5}\end{array}$ & $\begin{array}{c}\text { Reduction of } \\
\text { generated } \\
\text { load in the } \\
\text { period } \\
\text { (ton/year) }\end{array}$ & $\begin{array}{c}\text { \% } \\
\text { Variation }\end{array}$ \\
\hline DBO & 78.11 & 45.35 & 32.76 & -41.9 \\
\hline DQO & 207.6 & 122.53 & 85.07 & -40.9 \\
\hline TDS & 3.529 & 2.002 & 1.527 & -43.2 \\
\hline Nitrate & 1.94 & 0.93 & 1.01 & -52.1 \\
\hline $\begin{array}{l}\text { Phosphorous } \\
\text { Total }\end{array}$ & 0.59 & 0.20 & 0.39 & -66.1 \\
\hline
\end{tabular}

\subsection{Solid residues}

The volume of solid waste, include those destined for the sanitary landfill, to the barrel yard, to Treatment and Disposal Ditch (VTDs) and to the land farming. In 1998, occur the expansion works of installed capacity, a factor that contributed to the increasing of solid waste common generation, where the company started to produce more and therefore generate more waste. The actions taken with the EMS implantation, which occurred after the increase in waste generation, prove its efficiency by reducing the values, with greater representation in the years 2003 and 2004, this reduction being interrupted in 2005, which due the general maintenance stop, has increased from just over 7\% compared to 1998 , when it was obtained ISO 14001 certification.

Table 4: $\quad$ Variation index $(\%)$ in the generation of solid waste.

\begin{tabular}{|c|c|c|c|c|}
\hline \multirow{2}{*}{$\begin{array}{c}\text { Total } \\
\text { Volume }\end{array}$} & $\begin{array}{c}\mathbf{1 9 9 6} \\
\mathbf{( + 3 9 . 6 \%} \\
\text { expansion) }\end{array}$ & $\begin{array}{c}\text { Period Average } \\
\mathbf{1 9 9 7}-\mathbf{2 0 0 5}\end{array}$ & $\begin{array}{c}\text { Reduction of } \\
\text { generated } \\
\text { volume in the } \\
\text { period }\left(\mathbf{m}^{\mathbf{3}} / \mathbf{y e a r}\right)\end{array}$ & $\begin{array}{c}\text { \% } \\
\text { Variation }\end{array}$ \\
\cline { 2 - 5 } & 5972 & 3745 & 2227 & -37.2 \\
\hline
\end{tabular}

As observed in the research, there was a reduction in the total generation of solid waste and also increases in the values of recovery and recycling of solid waste generated by the company; strategies to be used in the future as part of the recycling of solid residue created after the EMS implantation. 
The results show the evolution and variation in the recovery and recycling of solid waste; in a broad analysis, the data shows that recycling increased immediately after environmental certification, followed by a slight decrease; this oscillation continued until 2000, since when there has been a gradual increase.

Therefore it can be understood that the solid residue that has ceased to be recycled after EMS implantation has been recovered or re-used within the same company, or forwarded to other companies as co-products.

The information contained in Table 5 shows that the percentage of recycled solid waste increase achieved a growth of $67.1 \%$, when compared to the year before EMS had been deployed. However, the value that was most surprising was the $530 \%$ increase in solid waste recovery.

Table 5: Variation Index (\%) of solid waste recycled and recovered $\left(\mathrm{m}^{3} /\right.$ year $)$.

\begin{tabular}{|l|c|c|c|c|}
\hline & $\begin{array}{c}\mathbf{1 9 9 6} \\
\mathbf{( + 3 9 . 6 \%} \\
\text { expansion) }\end{array}$ & $\begin{array}{c}\text { Period } \\
\text { Average } \\
\mathbf{1 9 9 7 - \mathbf { 2 0 0 5 }}\end{array}$ & $\begin{array}{c}\text { Increasing of } \\
\text { administered } \\
\text { volume in the } \\
\text { period }\left(\mathbf{m}^{\mathbf{3}} / \mathbf{y e a r}\right)\end{array}$ & $\begin{array}{c}\text { \% } \\
\text { Variation }\end{array}$ \\
\hline Recycling & 2867 & 4791 & 1924 & $+67,1$ \\
\hline Recovering & 392 & 2471 & 2079 & $+530,3$ \\
\hline
\end{tabular}

With regard to the solid waste, it is also pertinent to analyze the values of ash generated in coal burning for energy generation through the boilers.

It can be observed that there was reduction in ash generation after the EMS implantation, if compared to the year 1996. However, in subsequent years the company reduced the regeneration of this waste due to the use of natural gas as an energy source, from the year 2000, replacing part of the use of coal, which in turn gives rise to ashes. Therefore part of the reduction is attributed to the change of the company's energy matrix. The year 2005 presents over the average of the period in study, evidence not described in the reports used for this research; but, according to information obtained through phone calls to the Office Of People, Management and Safety and Environment of the company, this increase was possible because of problems with the marketing of natural gas in the country that exports it to Brazil.

Table 6: $\quad$ Variation index (\%) ashes generated in coal burning.

\begin{tabular}{|c|c|c|c|c|}
\hline & $\begin{array}{c}\mathbf{1 9 9 6} \\
\mathbf{( + 3 9 . 6 \%} \\
\text { expansion) }\end{array}$ & $\begin{array}{c}\text { Period } \\
\text { Average } \\
\mathbf{1 9 9 7}-\mathbf{2 0 0 5}\end{array}$ & $\begin{array}{c}\text { Reduction of } \\
\text { generated volume in } \\
\text { the period (t/year) }\end{array}$ & $\begin{array}{c}\text { \% } \\
\text { Variation }\end{array}$ \\
\hline Volume & 203.331 & 87.921 & 115.410 & -56.7 \\
\hline
\end{tabular}

Even when showing an increase in the volume generated in the last year of analysis, the company presented a decrease of $57.7 \%$ in the volume of generated 
ashes in the year, if compared to the figures for the year 1996, as shown in Table 6. In addition to the ashes becoming in themselves economically viable, there are also economic benefits for the company.

\subsection{Water consumption}

The results show the raw water consumption in cubit meters per year, during the examined years, as well as the total value (108.822, 934 cubit meters per year) and the average of water consumed $(12.091,437$ cubit meters per year) in the period 1996 to 2005 .

The year 1999 showed a significant increase in the raw water consumption. This happened because of procedures necessary for the completion of expansion works of the company's productive capacity, through the washing of pipes and the checking of new systems. However, these levels of water consumption were still lower when compared to the 1996 levels, when one of the company maintenance stops occurred.

The data shows that after certification, as well as after the company's expansion of the installed capacity, the raw water consumption has remained at an average of just over 12 million cubit meters per year.

Table 7: $\quad$ Variation index (\%) in raw water.

\begin{tabular}{|c|c|c|c|c|}
\hline & $\begin{array}{c}\mathbf{1 9 9 6} \\
\mathbf{+ 3 9 . 6 \%} \\
\text { expansion) }\end{array}$ & $\begin{array}{c}\text { Period } \\
\text { Average } \\
\mathbf{1 9 9 7 -} \\
\mathbf{2 0 0 5}\end{array}$ & $\begin{array}{c}\text { Reduction of } \\
\text { consumed } \\
\text { volume in the } \\
\text { period }\left(\mathbf{m}^{3} / \text { year }\right)\end{array}$ & $\begin{array}{c}\text { \% } \\
\text { Variation }\end{array}$ \\
\hline Consumption & $13,441.718$ & $12,091.437$ & $1,350.281$ & -10.0 \\
\hline
\end{tabular}

Analyzing table 7 , it can be presumed that in the period after the installed capacity expansion of the company, there was a slight reduction in raw water consumption, presenting a consumption reduction of $10 \%$, if compared to 1996 , when EMS was not yet operating.

The reduction in water consumption is due in the main to the current increase of the re-use of water within the cycles of the cooling systems.

Through obtained information, the company COPESUL is also developing a project to re-use the water, aiming to make this reduction more apparent and improve their environmental performance in this aspect too.

\subsection{Energy consumption}

The results present values on energy consumption over given analyzed years, in addition to the parameters for the environmental performance analysis. The average consumption of electrical energy in the period of 1996 - 2005 was 10,189.732 $\mathrm{MWh}$ - and the total consumption was 91,707.596 MWh/year.

The data about energy consumption shows an increase in electric energy consumption after the EMS certification, which is justified on the grounds that, during that same period, the expansion works of the productive capacity of the 
company were being established. After 2000, the subsequent years showed less variation despite boilers being used as an energy source and, in 2001, the introduction of natural gas in the energy matrix of the company. The data shows that where was only reduction in electrical energy consumption in the year of this introduction, because in subsequent years there was an increase, which was maintained at the same average up to 2005 .

According to information provided by the Office of People Management, Safety and Environment for the company, electric energy consumption has not diminished with the use of natural gas because there is not gas available in the necessary quantities to supply company demand. However, the data for the year 2006 would show a reversal trend; i.e: an increase of natural gas consumption and a subsequent decrease in electrical energy consumption.

Table 8 shows that, notwithstanding an increase in electrical energy consumption, during the period under study, when the average consumption is measured against consumption in 1996, it is still possible to reach positive results, results which reached a percentage higher than $26 \%$ of consumption reduction.

Table 8: $\quad$ Variation index (\%) in the electric energy consumption.

\begin{tabular}{|c|c|c|c|c|}
\hline Years & $\begin{array}{c}\mathbf{1 9 9 6} \\
\mathbf{+}+\mathbf{3 9 . 6 \%} \\
\text { expansion) }\end{array}$ & $\begin{array}{c}\text { Period } \\
\text { Average } \\
\mathbf{1 9 9 7 - 2 0 0 5}\end{array}$ & $\begin{array}{c}\text { Consumption } \\
\text { reduction in } \\
\text { the period } \\
(\text { MW h/year) }\end{array}$ & $\begin{array}{c}\text { \% } \\
\text { Variation }\end{array}$ \\
\hline Consumption & 13.889 .419 & 10.189 .732 & 3.699 .687 & $-26,6 \%$ \\
\hline
\end{tabular}

\section{Final considerations}

The guarantee of competitiveness and profit is the main objective in any strategic decision taken by an organization. Therefore, investments in the environmental area may not be attractive initially, especially if they are not thought in intangibles gains, in maintaining the company image before the society and the elements involved, as consumers and investors.

Profit motivation is not described by COPESUL as relevant when companies only justify their investment in the environment by future profit gains, but when both the environment and their respect and commitment to the community and their collaborators is wholly taken into consideration and realized.

However, after analyzing financial returns obtained by COPESUL, it is clear that the whole package of environmental investments would be attractive to any companies wishing to do the same, because it has been proved that, apart from giving an organization a positive image of sustainable production, and improved eco-efficiency, it also guarantees economic profit.

Note: it should be remembered that this case study has been limited to the environmental aspects that could be quantified; but has not looked at more intangible profits that a company might gain with an EMS certification by NBR ISO - 14001 . 


\section{References}

[1] Donaire, D. Gestão Ambiental na Empresa. São Paulo: Atlas, 1995.

[2] Souza, R. S. Evolução e Condicionantes da Gestão Ambiental nas Empresas. REAd - Revista Eletrônica de Administração. Porto Alegre, 8 (6), nov-dez 2002.

[3] Varadarajan, P. R. Marketing's Contributions to Strategy: the view from a different looking glass. In Journal of The Academy of Marketing Science. Miami, Academy of Marketing Science. 20, 1992.

[4] Macdonald, J. P. Strategic sustainable development using the ISO 14001 Standard. Journal of Cleaner Production, 13, may. 2005, p. 631-643.

[5] Shank, J. K., Govindarajan, V. A Revolução dos Custos. Rio de Janeiro: Campus, 1997.

[6] Hansen, D. R.; Mowen, M. M. Gestão de Custos: Contabilidade e Controle. São Paulo: Pioneira, 2001.

[7] Líbera, K. A. D. Análise da Gestão Estratégica dos Custos de Natureza Ambiental: Estudo de Caso em uma Empresa do Setor Cerâmico. 2003. Dissertação. Universidade Federal de Santa Catarina, Florianópolis, 2003.

[8] Jasch, C. Environmental Management Accounting: Procedures and Principles. United Nations New York, 2001. Online. $<$ http://www.emawebsite.org/library_favorites.asp $>$.

[9] Lavorato, M. L. A. A Evolução da Percepção da Variável Ambiental sob a Ótica da Gestão. 2003. Online <http://www.eco2000.com.br/ ecoviagem/ecoestudos/evolucao. pdf $>$.

[10] Associação Brasileira de Normas Técnicas - ABNT. NBR ISO 14031:2004. Gestão Ambiental - Avaliação de Desempenho Ambiental Diretrizes. Rio de Janeiro: ABNT, 2004.

[11] Gheno, R. Sistema de Gestão Ambiental e Benefícios para a organização: estudo de caso em empresa metalúrgica do RS. 2006. Dissertação (Mestrado em Engenharia). Universidade de Passo Fundo, Passo Fundo, 2006.

[12] Reis, M. J. L. ISO 14000 - Gerenciamento Ambiental: Um novo Desafio para a sua Competitividade. Rio de Janeiro: Qualitymark, 1995.

[13] Tibor, T., Feldman, I. ISO 14000 Um Guia para as Novas Normas de Gestão Ambiental. São Paulo, Futura: 1996.

[14] Maranhão, M. Uma fronteira entre avanço e retrocesso. São Paulo: Banas, 1998.

[15] COPESUL - Companhia Petroquímica do Sul. Relatório de Desempenho: Segurança, Saúde e Meio Ambiente. Companhia Petroquímica do Sul, 1998; 2000;2005.

[16] Associação Brasileira de Normas Técnicas - ABNT. NBR ISO 14001:1996. Sistemas de Gestão Ambiental - Especificações e Diretrizes para Uso. Rio de Janeiro: ABNT, 1997. 